\title{
MENENTUKAN PREMI ASURANSI JIWA JOINT LIFE UNTUK TIGA ORANG TERTANGGUNG
}

Vivin Aprilia Manjaruni ${ }^{1}$, I Gusti Putu Purnaba ${ }^{2}$

${ }^{1}$ Program Studi Matematika Terapan, FMIPA- Institut Pertanian Bogor

Email: vivinapriliamanjaruni@gmail.com

${ }^{2}$ Program Studi Matematika Terapan, FMIPA- Institut Pertanian Bogor

Email:purnaba@gmail.com

\begin{abstract}
The impact of Covid-19 in 2020 has resulted in people being susceptible to disease and even death. This has an impact on financial losses due to the large cost of hospitalization. Therefore, the use of life insurance will protect the family from financial loss with compensation or sum insured that will be provided by the insurance company. Joint life insurance is a type of insurance that can pay a premium at the first death of an insured party. Based on the needs of the Indonesian people in the midst of the current pandemic, the appropriate life insurance is a type of joint life insurance.

This study aims to determine the total annual premium for co-living for a household consisting of three people, consisting of a husband and wife partner and their son, using the annual premium formula. In addition, this study also aims to compare whether a husband's young age affects the size of the premium costs that must be based on.

Based on the results of the calculations and comparisons studied, a couple of 30 years, a wife of 30 years and a son of 10 years with an insurance period of 5 years and a compensation of 1 rupiah and an interest rate of 6\% will pay a premium of 0.1893 rupiah which is smaller than the age of the husband above. 30 years using the 2019 Indonesian Mortality Table.
\end{abstract}

Keywords: Insurance, Joint Life Status, Interest Rate, Compensation.

ABSTRAK

Dampak Covid-19 di tahun 2020 mengakibatkan masyarakat rentan untuk terserang penyakit bahkan bisa sampai meninggal dunia. Hal ini berdampak pada kerugian finansial akibat biaya perawatan di rumah sakit yang tidak sedikit. Oleh sebab itu, dengan penggunaan asuransi jiwa akan melindungi keluarga dari kerugian finansial dengan adanya santunan atau uang pertanggungan yang akan diberikan oleh perusahaan asuransi. Asuransi jiwa joint life adalah jenis asuransi yang dapat membayar premi saat kematian pertama salah satu pihak yang dipertanggungkan. Berdasarkan kebutuhan masyarakat Indonesia di tengah pandemi sekarang, maka asuransi jiwa yang sesuai adalah jenis asuransi jiwa joint life.

Penelitian ini bertujuan untuk mengetahui jumlah premi tahunan asuransi jiwa joint life untuk satu rumah tangga beranggotakan tiga orang yang terdiri dari sepasang suami istri dan satu putra mereka, dengan menggunakan formula premi tahunan. Selain itu, penelitian ini juga bertujuan untuk membandingkan apakah tua mudanya usia seorang suami mempengaruhi besar kecilnya biaya premi yang harus dibayarkan.

Berdasarkan hasil perhitungan dan perbandingan yang diteliti maka suami 30 tahun, istri 30 tahun dan putra 10 tahun dengan masa asuransi 5 tahun dan besar santunan 1 rupiah serta tingkat bunga 6\% akan membayar premi 0,1893 rupiah yang lebih kecil dibandingkan dengan usia suami di atas 30 tahun menggunakan Tabel Mortalita Indonesia Tahun 2019.

Kata kunci: Asuransi, Status Joint Life, Tingkat Suku Bunga, Santunan. 


\section{PENDAHULUAN}

Tahun 2020 merupakan tahun yang cukup berat bagi masyarakat Indonesia dan dunia, dikarenakan dampak Covid-19 yang mengakibatkan seseorang rentan untuk terserang penyakit bahkan bisa sampai meninggal dunia. Hal itu membuat masyarakat harus menjalankan beberapa protokol kesehatan agar tidak terserang penyakit tersebut. Selain menjalankan protokol kesehatan, penting juga bagi masyarakat untuk mengikuti asuransi jiwa. Dengan demikian keluarga mereka dapat terlindung dengan asuransi tersebut sehingga perekonomian keluarga tidak menurun drastis jika salah satu anggota keluarganya terserang Covid-19.

Asuransi jiwa akan melindungi keluarga dengan diberikannya sejumlah uang yang disebut santunan atau uang pertanggungan oleh perusahaan asuransi. Pihak tertanggung (keluarga yang mengikuti asuransi) juga mempunyai kewajiban kepada perusahaan asuransi jiwa untuk membayar premi.

Asuransi jiwa dapat dibedakan menurut jumlah orang yang terikat kontrak asuransi yaitu asuransi jiwa single life dan asuransi jiwa multi life. Asuransi jiwa single life adalah perjanjian asuransi yang melibatkan hidup atau mati satu orang. Sementara itu, asuransi jiwa multi life adalah perjanjian asuransi yang melibatkan hidup atau mati dari kombinasi dua orang atau lebih (seperti suami dan istri atau orang tua dan anak) (Futami, 1994).

Asuransi jiwa multi life dibagi menjadi dua bagian sesuai dengan jangka waktu pembayarannya, yaitu joint life dan last survivor. Asuransi jiwa joint life adalah jenis asuransi yang dapat membayar manfaat/santunan saat kematian pertama salah satu pihak yang dipertanggungkan. Berbeda dengan itu, asuransi jiwa last survivor adalah asuransi yang membayar manfaat/santunan asuransi kepada tertanggung setelah kematian terakhir pihak yang dipertanggungkan (Frostig dan Levikson, 2003). Berdasarkan kebutuhan masyarakat Indonesia di tengah pandemi sekarang, maka asuransi jiwa yang sesuai adalah jenis asuransi jiwa joint life.

Penggunaan asuransi jiwa, bisa membantu keluarga. Karena jika nanti meninggal, sisa keluarga akan mendapatkan warisan dari klaim asuransi (Economy.okezone.com, 2020).

Jika keluarga dilindungi, kerugian ekonomi tertanggung (pelanggan) karena sakit, kecelakaan, kematian dan kecelakaan lainnya bisa diminimalisir (Medcom.id, 2020).

Strategi terbaik untuk meningkatkan ketahanan terhadap risiko yang tidak terduga adalah dengan membekali diri dengan rencana keuangan, seperti asuransi jiwa dan dana darurat yang memberikan manfaat jangka panjang dan keamanan finansial (Liputan6.com, 2021).

Hal itu dikarenakan besar santunan yang akan diterima dari meninggalnya salah seorang anggota keluarga tertanggung dapat tetap menyokong kestabilan perekonomian keluarga yang ditinggalkan, terutama jika yang meninggal adalah kepala keluarga.

Oleh karena itu, pada karya ilmiah ini penulis akan menganalisis perhitungan premi tahunan asuransi jiwa berjangka bagi pemegang asuransi jiwa bersama (joint life) untuk tiga tertanggung, yaitu orang tua dan anak.

\section{METODOLOGI}

\subsection{Perumusan Suku Bunga, Anuitas dan Asuransi Berjangka Joint Life.}

\section{SUKU BUNGA}

Jenis suku bunga ada dua yaitu bunga sederhana dan bunga majemuk. Bunga sederhana dihitung berdasarkan rasio pokok terhadap jangka waktu investasi. Bunga majemuk adalah 
perhitungan pokok, dan periode investasi adalah jumlah pokok sebelumnya dan bunga yang diperoleh.

Investasi dengan nilai sekarang 1 akan diakumulasikan sebagai $(i+1)$ pada akhir periode 1. Nilai sekarang juga dikenal sebagai faktor diskonto yang diwakili oleh $v$, yaitu (Futami T, 1994):

Di mana:

$$
v^{t}=\frac{1}{(i+1)^{t}} .
$$

$i=$ tingkat suku bunga

$t=$ periode

$v^{t}=$ fungsi diskonto untuk periode $\mathrm{ke}-t$

\section{ANUITAS HIDUP DENGAN TUNDAAN N-TAHUN}

Suatu nilai sekarang aktuaria dengan pembayaran sebesar 1 oleh orang yang berumur $x$ tahun di awal tahun seumur hidup yang pembayarannya ditunda selama $n$-tahun dinotasikan ${ }_{n \mid} \ddot{a}_{x}$ dengan rumus sebagai berikut (Bowers NL, 1997):

$$
{ }_{n} \mid \ddot{a}_{x}=\sum_{k=n}^{\infty} v_{k}^{k} p_{x} \text {. }
$$

\section{ANUITAS AWAL}

Suatu nilai sekarang dari anuitas hidup dengan jangka $n$-tahun dan status joint life yang pembayarannya diawal tahun untuk $m$ orang atau lebih dan masih tetap hidup dengan rumus sebagai berikut (Futami T, 1994):

$$
\ddot{a}_{x_{1} x_{2} \ldots x_{m}: \overline{n \mid}}=1+v \cdot p_{x_{1} x_{2} \ldots x_{m}}+v^{2}{ }_{2} p_{x_{1} x_{2} \ldots x_{m}}+\cdots+v^{n-1}{ }_{n-1} p_{x_{1} x_{2} \ldots x_{m}}
$$

\section{PURE ENDOWMENT JOINT LIFE}

Suatu premi tunggal pure endowment joint life untuk anggota yang usianya $x, y$ dan $z$ tahun dirumuskan sebagai berikut (Futami T, 1994):

$$
A_{x y z: \frac{1}{n \mid}}=v^{n}{ }_{n} p_{x y z}
$$

\section{ASURANSI BERJANGKA JOINT LIFE DENGAN PREMI TUNGGAL}

Premi tunggal asuransi berjangka joint life untuk usia $x, y$ dan $z$ tahun dirumuskan sebagai berikut (Futami T, 1994):

$$
A_{x y z: \bar{n} \mid}^{1}=\sum_{t=1}^{n} v^{t}\left({ }_{t-1} p_{x y z}-{ }_{t} p_{x y z}\right)
$$

\subsection{RUMUSAN PREMI TAHUNAN}

Kontrak asuransi yang melibatkan suami, istri dan putra/putri dengan usia mereka $\mathrm{x}$, $\mathrm{y}$ dan $\mathrm{z}$ tahun. Selama peserta masih hidup, premi dapat dibayarkan dalam waktu $\mathrm{n}$ tahun. Penjelasan kontrak untuk uang pertanggungannya (benefit) adalah sebagai berikut:

a. Jika anggota berusia $x$ tahun, $y$ tahun dan $z$ tahun masih hidup sampai kontrak asuransi diputus, maka peserta dapat memperoleh asuransi sebesar $Q$.

b. Jika salah seorang anggota meninggal sebelum masa kontrak berakhir, dan dua anggota yang tersisa masih hidup sebelum kontrak diputus, mereka akan menerima jumlah pertanggungan tahunan, misalnya jika $x$ meninggal sebelum masa kontrak berakhir, pembayaran premi dihentikan. Jika $z$ masih hidup sampai akhir masa kontrak, maka $y$ dan $z$ dari tahun ke- $n$ akan menerima total $R_{y z}$ uang pertanggungan seumur hidup setiap tahunnya. Demikian pula, jika $y$ mati, $R_{x z}$ diberikan; jika $z$ mati, $R_{x y}$ diberikan.

c. Jika dua anggota meninggal sebelum kontrak diputus, dan satu anggota masih hidup setelah kontrak diputus, misalnya jika $x$ dan $y$ meninggal sebelum kontrak berakhir, 
maka premi akan diputus, dan jika $z$ bertahan hidup hingga kontrak diputus, maka total jumlah pertanggungan $R_{z}$ akan $z$ peroleh seumur hidup mulai tahun ke $n$. Demikian pula, jika $x$ dan $z$ mati $R_{y}$ diberikan, dan jika y dan z mati, $R_{x}$ diberikan.

d. Jika ada anggota $x, y$ atau $z$ meninggal sebelum kontrak diakhiri, ahli waris akan menerima jumlah total premi asuransi yang dibayarkan pada akhir tahun kematian.

Terkait dengan kontrak asuransi di atas, nilai tunai pendapatan premi asuransi dan nilai tunai benefit yang dibayarkan oleh penanggung dapat dinyatakan sebagai:

1. Nilai tunai oleh pendapatan premi tahunan dari asuransi jiwa joint life tiga orang dapat dirumuskan sebagai berikut:

$$
P \cdot\left(1+v \cdot p_{x y z}+v^{2}{ }_{2} p_{x y z}+\cdots+v^{n-1}{ }_{n-1} p_{x y z}\right)=P \cdot \ddot{a}_{x y z: \bar{n} \mid}
$$

2. Nilai tunai oleh pengembalian premi yang dibayarkan oleh penanggung dapat dirumuskan sebagai berikut:

$$
\begin{gathered}
Q \cdot A_{x y z: \frac{1}{n \mid}}+R_{y z}{ }_{n}\left|\ddot{a}_{y z}{ }_{n} q_{x}+R_{x z}{ }_{n}\right| \ddot{a}_{x z}{ }_{n} q_{y}+R_{x y}{ }_{n} \mid \ddot{a}_{x y}{ }_{n} q_{z}+ \\
R_{z}{ }_{n}\left|\ddot{a}_{z}{ }_{n} q_{\overline{x y}}+R_{x}{ }_{n}\right| \ddot{a}_{x}{ }_{n} q_{\overline{y z}}+R_{y}{ }_{n} \mid \ddot{a}_{y}{ }_{n} q_{\overline{x z}}+P \cdot A_{x y z: \bar{n} \mid}^{1}
\end{gathered}
$$

3. Dengan memanfaatkan prinsip kesetaraan maka besarnya premi dapat dirumuskan sebagai berikut:

$$
\begin{aligned}
& P \cdot \ddot{a}_{x y z: \bar{n} \mid}=Q \cdot A_{x y z: \frac{1}{n \mid}}+R_{y z}{ }_{n}\left|\ddot{a}_{y z}{ }_{n} q_{x}+R_{x z}{ }_{n}\right| \ddot{a}_{x z}{ }_{n} q_{y}+R_{x y}{ }_{n} \mid \ddot{a}_{x y}{ }_{n} q_{z}+ \\
& R_{z}{ }_{n}\left|\ddot{a}_{z}{ }_{n} q_{\overline{x y}}+R_{x} \cdot{ }_{n}\right| \ddot{a}_{x}{ }_{n} q_{\overline{y z}}+R_{y}{ }_{n} \mid \ddot{a}_{y}{ }_{n} q_{\overline{x z}}+P \cdot A_{x y z: \bar{n} \mid}^{1}
\end{aligned}
$$

Oleh karena itu, rumusan premi tahunan tiga orang yang harus dibayar oleh anggota asuransi jiwa joint life adalah (Bhuana TY, 2015):

$$
\begin{gathered}
P=\frac{1}{\ddot{a}_{x y z: \bar{n} \mid}-A_{x y z: \bar{n} \mid}^{1}} \times\left(Q \cdot A_{x y z: \frac{1}{n \mid}}+R_{y z}{ }_{n}\left|\ddot{a}_{y z}{ }_{n} q_{x}+R_{x z} \cdot{ }_{n}\right| \ddot{a}_{x z}{ }_{n} q_{y}+\right. \\
\left.R_{x y}{ }_{n}\left|\ddot{a}_{x y}{ }_{n} q_{z}+R_{z}{ }_{n}\right| \ddot{a}_{z}{ }_{n} q_{\overline{x y}}+R_{x}{ }_{n}\left|\ddot{a}_{x}{ }_{n} q_{\overline{y z}}+R_{y}{ }_{n}\right| \ddot{a}_{y}{ }_{n} q_{\overline{x z}}\right) .
\end{gathered}
$$

\section{HASIL DAN PEMBAHASAN}

\subsection{STUDI KASUS}

Pada bab ini akan dilakukan pembahasan terkait studi kasus untuk mensimulasikan penggunaan asuransi jiwa joint life untuk menentukan premi asuransi jiwa berjangka pada kasus tiga tertanggung (yaitu orang tua dan anak laki-laki) dengan menggunakan Tabel Mortalita Indonesia Tahun 2019. Hasil perhitungan premi, diperoleh dengan menggunakan bantuan software Microsoft Excel. Berikut merupakan contoh kasus yang akan disimulasikan untuk penentuan premi asuransi jiwa berjangka joint life dalam suatu keluarga yang terdiri atas suami, istri dan anaknya laki-laki.

\section{Contoh kasus 1:}

Pada tahun 2020, banyak sekali keluarga di Indonesia yang kesulitan dalam perekonomian mereka dikarenakan pandemi Covid-19. Bukan hanya itu, mereka juga khawatir akan terserang penyakit tersebut karena dapat menyebabkan kematian. Oleh sebab itu, seorang suami dengan usia 30 tahun mendaftarkan istri dan putranya yang berusia 30 tahun dan 10 tahun untuk membeli asuransi jiwa joint life. Premi asuransi tersebut harus mereka bayarkan setahun sekali untuk kontrak 5 tahun, dengan besar santunan sebesar 1 rupiah dan tingkat bunga $6 \%$. 
Maka diperoleh:

$\begin{array}{ll}n & =5 \text { tahun. } \\ i & =6 \%=0,06 . \\ \text { Umur suami } & =x=30 \text { tahun. } \\ \text { Umur istri } & =y=30 \text { tahun. } \\ \text { Umur anak laki-laki } & =z=10 \text { tahun. }\end{array}$

1. Nilai anuitas awal joint life menggunakan Persamaan (2):

$$
\begin{aligned}
\ddot{a}_{x, y, z: \bar{n}} & =\sum_{k=0}^{n-1} v^{k}{ }_{k} p_{x, y, z} \\
\ddot{a}_{30,30,10: \overline{5 \mid}} & =\sum_{k=0}^{5-1} v^{k}{ }_{k} p_{30,30,10} \\
& =\sum_{k=0}^{5-1} v^{k}\left({ }_{k} p_{30}\right)\left({ }_{k} p_{30}\right)\left({ }_{k} p_{10}\right) \\
& =4,4517
\end{aligned}
$$

2. Premi tunggal asuransi berjangka joint life menggunakan Persamaan (4):

$$
\begin{aligned}
A_{x y z: \bar{n} \mid}^{1} & =\sum_{t=1}^{n} v^{t}\left({ }_{t-1} p_{x y z}-{ }_{t} p_{x y z}\right) \\
A_{30,30,10: \overline{5} \mid}^{1} & =\sum_{t=1}^{5} v^{t}\left({ }_{t-1} p_{30,30,10}-{ }_{t} p_{30,30,10}\right) \\
& \left.=\sum_{t=1}^{5} v^{t}\left(\left({ }_{t-1} p_{30}\right)\left({ }_{t-1} p_{30}\right)\left({ }_{t-1} p_{10}\right)\right)-\left(\left({ }_{t} p_{30}\right)\left({ }_{t} p_{30}\right)\left({ }_{t} p_{10}\right)\right)\right) \\
& =0,00715
\end{aligned}
$$

3. Premi tunggal pure endowment joint life menggunakan Persamaan (3):

$$
\begin{aligned}
A_{x y z: \frac{1}{n \mid}} & =v^{n} \cdot{ }_{n} p_{x y z} \\
A_{30,30,10: \frac{1}{51}} & =v^{5} \cdot{ }_{5} p_{30,30,10} \\
& =\frac{1}{(0,06+1)^{5}} \cdot\left({ }_{5} p_{30}\right)\left({ }_{5} p_{30}\right)\left({ }_{5} p_{10}\right) \\
& =0,7408
\end{aligned}
$$

4. Anuitas hidup yang ditunda $n$-tahun menggunakan Persamaan (1):

$\mathrm{n} \quad=5$ tahun.

$\mathrm{i} \quad=6 \%=0,06$.

Umur suami $\quad=\mathrm{x}=30$ tahun.

Umur istri $\quad=\mathrm{y}=30$ tahun.

Umur anak laki-laki $=\mathrm{z}=10$ tahun.

a) Pada ${ }_{n} \mid \ddot{a}_{y z}$ dan ${ }_{n} q_{x}$ dengan batas sigmanya $k=5$ sampai $p=111-\min (y, z)=111-\min (30,10)=101:$

$$
\begin{aligned}
{ }_{n} \mid \ddot{a}_{y z} & =\sum_{k=n}^{p} v^{k}{ }_{k} p_{y z} \\
{ }_{5} \mid \ddot{a}_{30,10} & =\sum_{k=5}^{101} v^{k}{ }_{k} p_{30,10} \\
& =\sum_{k=5}^{101} v^{k}\left({ }_{k} p_{30}\right)\left({ }_{k} p_{10}\right) \\
& =11,8987 \\
{ }_{n} q_{x} & ={ }_{5} q_{30} \\
& =0,0043
\end{aligned}
$$

b) Pada ${ }_{n} \mid \ddot{a}_{x z}$ dan ${ }_{n} q_{y}$ dengan batas sigmanya $k=5$ sampai $p=111-\min (x, z)=111-\min (30,10)=101:$

$$
{ }_{n} \mid \ddot{a}_{x z} \quad=\sum_{k=n}^{p} v^{k}{ }_{k} p_{x z}
$$




$$
\begin{aligned}
{ }_{5} \mid \ddot{a}_{30,10} & =\sum_{k=5}^{101} v^{k}{ }_{k} p_{30,10} \\
& =\sum_{k=5}^{101} v^{k}\left({ }_{k} p_{30}\right)\left({ }_{k} p_{10}\right) \\
& =11,6462 \\
& ={ }_{5} q_{30} \\
& =0,0032
\end{aligned}
$$

c) Pada ${ }_{n} \mid \ddot{a}_{x y}$ dan ${ }_{n} q_{z}$ dengan batas sigmanya $k=5$ sampai

$$
\begin{aligned}
p=111-\min & (x, y)=111-\min (30,30)=81: \\
{ }_{n} \mid \ddot{a}_{x y} & =\sum_{k=n}^{p} v^{k}{ }_{k} p_{x y} \\
{ }_{5} \mid \ddot{a}_{30,30} & =\sum_{k=5}^{81} v^{k}{ }_{k} p_{30,30} \\
& =\sum_{k=5}^{81} v^{k}\left({ }_{k} p_{30}\right)\left({ }_{k} p_{30}\right) \\
& =11,3157 \\
{ }_{n} q_{z} & ={ }_{5} q_{10} \\
& =0,0009
\end{aligned}
$$

d) Pada ${ }_{n} \mid \ddot{a}_{z}$ dan ${ }_{n} q_{\overline{x y}}$ dengan batas sigmanya $k=5$ sampai

$$
\begin{aligned}
p=111-(z) & =111-(10)=101: \\
{ }_{n} \mid \ddot{a}_{z} & =\sum_{k=n}^{p} v^{k}{ }_{k} p_{z} \\
{ }_{5} \mid \ddot{a}_{10} & =\sum_{k=5}^{101} v^{k}{ }_{k} p_{10} \\
& =12,6963 \\
{ }_{n} q_{\overline{x y}} & ={ }_{5} q_{\overline{30,30}} \\
& =\left({ }_{5} q_{30}\right)\left({ }_{5} q_{30}\right) \\
& =0,000014
\end{aligned}
$$

e) Pada ${ }_{n} \mid \ddot{a}_{x}$ dan ${ }_{n} q_{\overline{y z}}$ dengan batas sigmanya $k=5$ sampai

$$
\begin{aligned}
p=111-(x) & =111-(30)=81: \\
{ }_{n} \mid \ddot{a}_{x} & =\sum_{k=n}^{p} v^{k}{ }_{k} p_{x} \\
{ }_{5} \mid \ddot{a}_{30} & =\sum_{k=5}^{81} v^{k}{ }_{k} p_{30} \\
& =11,8079 \\
{ }_{n} q_{\overline{y z}} & ={ }_{5} q \overline{30,10} \\
& =\left({ }_{5} q_{30}\right)\left({ }_{5} q_{10}\right) \\
& =3,22 E-06
\end{aligned}
$$

f) Pada ${ }_{n} \mid \ddot{a}_{y}$ dan ${ }_{n} q_{\overline{x z}}$ dengan batas sigmanya $k=5$ sampai

$$
\begin{aligned}
p=111-(y) & =111-(30)=81: \\
{ }_{n} \mid \ddot{a}_{y} & =\sum_{k=n}^{p} v^{k}{ }_{k} p_{y} \\
{ }_{5} \mid \ddot{a}_{30} & =\sum_{k=5}^{81} v^{k}{ }_{k} p_{30} \\
& =12,0813 \\
{ }_{n} q_{\overline{x z}} & ={ }_{5} q_{\overline{30,10}} \\
& =\left({ }_{5} q_{30}\right)\left({ }_{5} q_{10}\right) \\
& =4,34 E-06
\end{aligned}
$$

5. Premi tahunan joint life menggunakan Persamaan (5):

$$
\begin{aligned}
& P=\frac{1}{\ddot{a}_{x y z: \bar{n} \mid}-A_{x y z: \bar{n} \mid}^{1}} \times\left(Q \cdot A_{x y z: \frac{1}{n \mid}}+R_{y z}{ }_{n}\left|\ddot{a}_{y z}{ }{ }_{n} q_{x}+R_{x z}{ }{ }_{n}\right| \ddot{a}_{x z}{ }{ }_{n} q_{y}+\right. \\
& \left.R_{x y}{ }_{n}\left|\ddot{a}_{x y}{ }_{n} q_{z}+R_{z}{ }_{n}\right| \ddot{a}_{z}{ }_{n} q_{\overline{x y}}+R_{x}{ }_{n}\left|\ddot{a}_{x}{ }_{n} q_{\overline{y z}}+R_{y}{ }_{n}\right| \ddot{a}_{y}{ }_{n} q_{\overline{x z}}\right) \text {. }
\end{aligned}
$$




$$
\begin{aligned}
\hline= & \frac{1}{\ddot{a}_{30,30,10: 5 \mid}-A_{30,30,10: \overline{5} \mid}^{1}} \times\left(Q \cdot A_{30,30,10: \frac{1}{5 \mid}+R_{30,10} \cdot{ }_{5} \mid \ddot{a}_{30,10} \cdot{ }_{5} q_{30}+R_{30,10} \cdot}\right. \\
& { }_{5}\left|\ddot{a}_{30,10} \cdot{ }_{5} q_{30}+R_{30,30} \cdot{ }_{5}\right| \ddot{a}_{30,30} \cdot{ }_{5} q_{10}+R_{10} \cdot{ }_{5}\left|\ddot{a}_{10} \cdot{ }_{5} q_{30,30}+R_{30} \cdot{ }_{5}\right| \ddot{a}_{30} \cdot \\
& \left.{ }_{5} q_{30,10}+R_{30} \cdot{ }_{5} \mid \ddot{a}_{30} \cdot{ }_{5} q \overline{30,10}\right) . \\
= & 0,1893 \text { rupiah. }
\end{aligned}
$$

Berdasarkan contoh kasus di atas asuransi jiwa joint life, dalam kasus tiga orang yang diasuransikan, yaitu suami 30 tahun, istri 30 tahun dan putra 10 tahun dengan masa asuransi 5 tahun dan besar santunan 1 rupiah serta tingkat bunga 6\%. Premi asuransi yang harus mereka bayarkan setiap awal tahun adalah 0.1893 rupiah.

\section{Contoh kasus 2:}

Seorang suami dengan usia 50 tahun mendaftarkan istri dan puteranya yang berusia 45 tahun dan 20 tahun untuk membeli asuransi jiwa joint life. Premi asuransi tersebut harus mereka bayarkan setahun sekali untuk kontrak 5 tahun, dengan besar santunan sebesar 1 rupiah dan tingkat bunga $6 \%$.

Maka diperoleh:

$$
\begin{array}{ll}
\mathrm{n} & =5 \text { tahun. } \\
\mathrm{i} & =6 \%=0,06 . \\
\text { Umur suami } & =\mathrm{x}=50 \text { tahun. } \\
\text { Umur istri } & =\mathrm{y}=45 \text { tahun. } \\
\text { Umur anak laki-laki } & =\mathrm{z}=20 \text { tahun. }
\end{array}
$$

1. Nilai anuitas awal joint life menggunakan Persamaan (2):

$$
\begin{aligned}
\ddot{a}_{x, y, z: \bar{n}} & =\sum_{k=0}^{n-1} v^{k}{ }_{k} p_{x, y, z} \\
\ddot{a}_{50,45,20: \overline{5} \mid} & =\sum_{k=0}^{5-1} v^{k}{ }_{k} p_{50,45,20} \\
& =\sum_{k=0}^{5-1} v^{k}\left({ }_{k} p_{50}\right)\left({ }_{k} p_{45}\right)\left({ }_{k} p_{20}\right) \\
& =4,3973
\end{aligned}
$$

2. Premi tunggal asuransi berjangka joint life menggunakan Persamaan (4):

$$
\begin{aligned}
A_{x y z: \bar{n} \mid}^{1} & =\sum_{t=1}^{n} v^{t}\left({ }_{t-1} p_{x y z}-{ }_{t} p_{x y z}\right) \\
A_{50,45,20: \overline{5} \mid}^{1} & =\sum_{t=1}^{5} v^{t}\left({ }_{t-1} p_{50,45,20}-{ }_{t} p_{50,45,20}\right) \\
& =\sum_{t=1}^{5} v^{t}\left(\left(\left({ }_{t-1} p_{50}\right)\left({ }_{t-1} p_{45}\right)\left({ }_{t-1} p_{20}\right)\right)-\left(\left({ }_{t} p_{50}\right)\left({ }_{t} p_{45}\right)\left({ }_{t} p_{20}\right)\right)\right) \\
& =0,0366
\end{aligned}
$$

3. Premi tunggal pure endowment joint life menggunakan Persamaan (3):

$$
\begin{aligned}
A_{x y z: \frac{1}{n \mid}} & =v^{n} \cdot{ }_{n} p_{x y z} \\
A_{50,45,20: \frac{1}{5 \mid}} & =v^{5} \cdot{ }_{5} p_{50,45,20} \\
& =\frac{1}{(0,06+1)^{5}} \cdot\left({ }_{5} p_{50}\right)\left({ }_{5} p_{45}\right)\left({ }_{5} p_{20}\right) \\
& =0,7145
\end{aligned}
$$

4. Anuitas hidup yang ditunda $n$-tahun menggunakan Persamaan (1):

$$
\begin{array}{ll}
\mathrm{n} & =5 \text { tahun. } \\
\mathrm{i} & =6 \%=0,06 . \\
\text { Umur suami } & =\mathrm{x}=50 \text { tahun. } \\
\text { Umur istri } & =\mathrm{y}=45 \text { tahun. } \\
\text { Umur anak laki-laki } & =\mathrm{z}=20 \text { tahun. }
\end{array}
$$


a) Pada ${ }_{n} \mid \ddot{a}_{y z}$ dan ${ }_{n} q_{x}$ dengan batas sigmanya $k=5$ sampai $p=111-\min (y, z)=111-\min (45,20)=91$ :

$$
\begin{aligned}
{ }_{n} \mid \ddot{a}_{y z} & =\sum_{k=n}^{p} v^{k}{ }_{k} p_{y z} \\
{ }_{5} \mid \ddot{a}_{45,20} & =\sum_{k=5}^{91} v^{k}{ }_{k} p_{45,20} \\
& =\sum_{k=5}^{91} v^{k}\left({ }_{k} p_{45}\right)\left({ }_{k} p_{20}\right) \\
& =10,6394 \\
{ }_{n} q_{x} & ={ }_{5} q_{50} \\
& =0,0303
\end{aligned}
$$

b) Pada ${ }_{n} \mid \ddot{a}_{x z}$ dan ${ }_{n} q_{y}$ dengan batas sigmanya $k=5$ sampai $p=111-\min (x, z)=111-\min (50,20)=91:$

$$
\begin{aligned}
{ }_{n} \mid \ddot{a}_{x z} & =\sum_{k=n}^{p} v^{k}{ }_{k} p_{x z} \\
{ }_{5} \mid \ddot{a}_{50,20} & =\sum_{k=5}^{91} v^{k}{ }_{k} p_{50,20} \\
& =\sum_{k=5}^{91} v^{k}\left({ }_{k} p_{50}\right)\left({ }_{k} p_{20}\right) \\
& =9,5429 \\
{ }_{n} q_{y} & ={ }_{5} q_{45} \\
& =0,0115
\end{aligned}
$$

c) Pada ${ }_{n} \mid \ddot{a}_{x y}$ dan ${ }_{n} q_{z}$ dengan batas sigmanya $k=5$ sampai $p=111-\min (x, y)=111-\min (50,45)=66$ :

$$
\begin{aligned}
{ }_{n} \mid \ddot{a}_{x y} & =\sum_{k=n}^{p} v^{k}{ }_{k} p_{x y} \\
{ }_{5} \mid \ddot{a}_{50,45} & =\sum_{k=5}^{66} v^{k}{ }_{k} p_{50,45} \\
& =\sum_{k=5}^{66} v^{k}\left({ }_{k} p_{50}\right)\left({ }_{k} p_{45}\right) \\
& =8,9774 \\
{ }_{n} q_{z} & ={ }_{5} q_{20} \\
& =0,0025
\end{aligned}
$$

d) Pada ${ }_{n} \mid \ddot{a}_{z}$ dan ${ }_{n} q_{\overline{x y}}$ dengan batas sigmanya $k=5$ sampai

$$
\begin{aligned}
p=111-(z) & =111-(20)=91: \\
{ }_{n} \mid \ddot{a}_{z} & =\sum_{k=n}^{p} v^{k}{ }_{k} p_{z} \\
{ }_{5} \mid \ddot{a}_{20} & =\sum_{k=5}^{91} v^{k}{ }_{k} p_{20} \\
& =12,3582 \\
{ }_{n} q_{\overline{x y}} & ={ }_{5} q_{50,45} \\
& =\left({ }_{5} q_{50}\right)\left({ }_{5} q_{45}\right) \\
& =0,00035
\end{aligned}
$$

e) Pada ${ }_{n} \mid \ddot{a}_{x}$ dan ${ }_{n} q_{\overline{y z}}$ dengan batas sigmanya $k=5$ sampai $p=111-(x)=111-(50)=61$ :

$$
\begin{aligned}
{ }_{n} \mid \ddot{a}_{x} & =\sum_{k=n}^{p} v^{k}{ }_{k} p_{x} \\
{ }_{5} \mid \ddot{a}_{50} & =\sum_{k=5}^{61} v^{k}{ }_{k} p_{50} \\
& =9,6919 \\
{ }_{n} q_{\overline{y z}} & ={ }_{5} q_{\overline{45,20}} \\
& =\left({ }_{5} q_{45}\right)\left({ }_{5} q_{20}\right) \\
& =2,83 E-05
\end{aligned}
$$

f) Pada ${ }_{n} \mid \ddot{a}_{y}$ dan ${ }_{n} q_{\overline{x z}}$ dengan batas sigmanya $k=5$ sampai $p=111-(y)=111-(45)=66:$ 


$$
\begin{aligned}
{ }_{n} \mid \ddot{a}_{y} & =\sum_{k=n}^{p} v^{k}{ }_{k} p_{y} \\
{ }_{5} \mid \ddot{a}_{45} & =\sum_{k=5}^{66} v^{k}{ }_{k} p_{45} \\
& =10,862 \\
{ }_{n} q \overline{x_{\overline{x z}}} & ={ }_{5} q_{50,20} \\
& =\left({ }_{5} q_{50}\right)\left({ }_{5} q_{20}\right) \\
& =7,45 E-05
\end{aligned}
$$

5. Premi tahunan joint life menggunakan Persamaan (5):

$$
\begin{aligned}
& P=\frac{1}{\ddot{a}_{x y z: \bar{n} \mid}-A_{x y z: \bar{n} \mid}^{1}} \times\left(Q \cdot A_{x y z: \frac{1}{n \mid}}+R_{y z}{ }_{n}\left|\ddot{a}_{y z}{ }_{n} q_{x}+R_{x z}{ }_{n}\right| \ddot{a}_{x z} \cdot{ }_{n} q_{y}+\right. \\
& \left.R_{x y}{ }_{n}\left|\ddot{a}_{x y}{ }_{n} q_{z}+R_{z}{ }^{n}\right| \ddot{a}_{z}{ }_{n} q_{\overline{x y}}+R_{x}{ }_{n}\left|\ddot{a}_{x}{ }_{n} q_{\overline{y z}}+R_{y}{ }_{n}\right| \ddot{a}_{y}{ }_{n} q_{\overline{x z}}\right) \text {. } \\
& P=\frac{1}{\ddot{a}_{50,45,20: 5 \mid}-A_{50,45,20: 5 \mid}^{1}} \times\left(Q \cdot A_{50,45,20: \frac{1}{5 \mid}}+R_{45,20} \cdot{ }_{5} \mid \ddot{a}_{45,20} \cdot{ }_{5} q_{50}+R_{50,20} .\right. \\
& { }_{5}\left|\ddot{a}_{50,20} \cdot{ }_{5} q_{45}+R_{50,45} \cdot{ }_{5}\right| \ddot{a}_{50,45} \cdot{ }_{5} q_{20}+R_{20} \cdot{ }_{5}\left|\ddot{a}_{20} \cdot{ }_{5} q_{50,45}+R_{50}{ }^{\cdot}{ }_{5}\right| \ddot{a}_{50} \cdot \\
& \left.{ }_{5} q \overline{45,20}+R_{45} \cdot{ }_{5} \mid \ddot{a}_{45} \cdot{ }_{5} q \overline{50,20}\right) \text {. } \\
& =0,2692 \text { rupiah. }
\end{aligned}
$$

Berdasarkan contoh kasus di atas asuransi jiwa joint life, dalam kasus tiga orang yang diasuransikan, yaitu suami 50 tahun, istri 45 tahun dan putra 20 tahun dengan masa asuransi 5 tahun dan besar santunan 1 rupiah serta tingkat bunga 6\%. Premi asuransi yang harus mereka bayarkan setiap awal tahun adalah 0,2692 rupiah.

\subsection{PERBANDINGAN PREMI BERDASARKAN USIA SUAMI}

Hal yang mendasari perbedaan besarnya suatu premi asuransi ialah perbedaan jenis kelamin, usia dan suku bunganya. Oleh karena itu, akan diuji dan dibandingkan apakah tua mudanya usia seorang suami akan mempengaruhi besar premi yang harus dibayarkan, dan apakah jika usia suami sama dengan istrinya maka akan juga mempengaruhi besar premi yang harus dibayarkan. Sehingga untuk melihat hal-hal tersebut maka dibuat simulasi usia seperti di bawah ini:

- Jika suami berusia 30 tahun dengan istri 30 tahun dan putra 10 tahun.

- Jika suami berusia 35 tahun dengan istri 30 tahun dan putra 10 tahun.

- Jika suami berusia 40 tahun dengan istri 30 tahun dan putra 10 tahun.

- Jika suami berusia 45 tahun dengan istri 45 tahun dan putra 20 tahun.

- Jika suami berusia 50 tahun dengan istri 45 tahun dan putra 20 tahun.

Dengan tingkat suku bunga 6\% maka diperoleh hasil sebagai berikut:

Tabel 1 Perbandingan Besarnya Premi Berdasarkan Usia Suami

\begin{tabular}{cccccc}
\hline $\begin{array}{c}\text { Kontrak } \\
\boldsymbol{n} \text {-tahun }\end{array}$ & $\begin{array}{c}\text { Suku } \\
\text { Bunga }\end{array}$ & $\begin{array}{c}\text { Usia } \\
\text { Suami }\end{array}$ & $\begin{array}{c}\text { Usia } \\
\text { Istri }\end{array}$ & $\begin{array}{c}\text { Usia Anak } \\
\text { Laki-Laki }\end{array}$ & $\begin{array}{c}\text { Premi Tahunan } \\
\text { Asuransi Jiwa Joint } \\
\text { Life } \text { Tiga Orang }\end{array}$ \\
\hline 5 & $6 \%$ & 30 & 30 & 10 & 0,1893 rupiah \\
5 & $6 \%$ & 35 & 30 & 10 & 0,1953 rupiah \\
5 & $6 \%$ & 40 & 30 & 10 & 0,2058 rupiah \\
5 & $6 \%$ & 45 & 45 & 20 & 0,2431 rupiah \\
5 & $6 \%$ & 50 & 45 & 20 & 0,2692 rupiah \\
\hline
\end{tabular}

Berdasarkan Tabel 1 tersebut, dapat diperoleh informasi sebagai berikut: Ketika suami lebih 
tua dari istri, premi asuransi yang diperoleh lebih besar daripada ketika suami dan istri seumuran. Misalnya suami berumur 50 tahun, istri 45 tahun, putra 20 tahun, dan tingkat bunga $6 \%$, premi yang diperoleh adalah 0,2692 rupiah. Premi yang diterima lebih tinggi dari pada suami yang berumur 30 tahun, isteri 30 tahun, putra 10 tahun dan tingkat bunga $6 \%$ (yaitu 0,1893 rupiah).

\section{KESIMPULAN}

Asuransi jiwa joint life adalah jenis asuransi yang dapat membayar premi saat kematian pertama salah satu pihak yang dipertanggungkan. Oleh karena itu, asuransi tersebut dapat membantu perekonomian keluarga yang anggota keluarganya (kepala keluarganya) meninggal akibat Covid-19. Berdasarkan hasil perhitungan dan perbandingan yang diteliti maka suami 30 tahun, istri 30 tahun dan putra 10 tahun dengan masa asuransi 5 tahun dan besar santunan 1 rupiah serta tingkat bunga 6\% akan membayar premi 0,1893 rupiah yang lebih kecil dibandingkan dengan usia suami di atas 30 tahun menggunakan Tabel Mortalita Indonesia Tahun 2019.

\section{DAFTAR PUSTAKA}

Bowers NL, Gerber HU, Hickman JC, Jones DA, Nessbit CJ. (1997). Actuarial Mathematics. Illinois (US). Society of Actuaries.

Bhuana TY, Widana IN, Harini LPI. (2015). Menentukan premi tahunan untuk tiga orang pada asuransi jiwa hidup gabungan (Joint Life). E-Jurnal Matematika. 4(4):195-200.

Economy.okezone.com. (2020, 14 Agustus). Pentingnya Asuransi Kesehatan dan Jiwa saat Pandemi Covid-19. Diakses pada 07 Desember 2020, dari https://economy.okezone.com/read/2020/08/14/320/2262320/pentingnya-asuransikesehatan-dan-jiwa-saat-pandemi-covid-19.

Futami T. (1994). Matematika Asuransi Jiwa Bagian II. Herliyanto G, penerjemah. Jakarta (ID). Oriental Life Insurance Cultural Development Center. Terjemahan dari: Seime Hoken Sugaku Gekan.

Frostig E, Levikson B. (2003). The Impact of Statistical Dependence on Multiple Life Insurance Programs. Departement of Statistics. Haifa (IL): University of Haifa.

Liputan6.com. (2021, 11 Januari). Pentingnya Asuransi di Tengah Ketidakpastian Akibat Pandemi Covid-19. Diakses pada 14 Januari 2020, dari https://www.liputan6.com/bisnis/read/4454512/pentingnya-asuransi-di-tengahketidakpastian-akibat-pandemi-covid-19.

Medcom.id. (2020, 01 Juli). Asuransi Jadi Kebutuhan di Tengah Pandemi Covid-19. Diakses pada $07 \quad$ Desember 2020, dari https://www.medcom.id/ekonomi/keuangan/zNAYWGAN-asuransi-jadi-kebutuhandi-tengah-pandemi-covid-19. 